\begin{abstract}
STRESZCZENIE
Peroksysomy to wielofunkcyjne organelle, które spełniają kluczową rolę w licznych procesach biochemicznych dostosowując się dynamicznie do aktualnych wymogów fizjologicznych komórki. Zaburzenie struktury peroksysomów na skutek mutacji i dysfunkcji genów PEX lub innych genów kodujących białka biogenezy czy pojedyncze peroksysomalne białka funkcyjne stanowi podłoże patogenetyczne chorób peroksysomalnych. Proces $\beta$-oksydacji bardzo długołańcuchowych kwasów tłuszczowych (VLCFA) jest unikalnym szlakiem metabolicznym zlokalizowanym wyłącznie $\mathrm{w}$ peroksysomie. To warunkuje, że VLCFA jest głównym biomarkerem $w$ diagnostyce chorób peroksysomalnych. Choroby peroksysomalne prezentują szerokie spektrum objawów klinicznych od neonatalnego, ciężkiego Zespołu Zellwegera z dysmorfią, dysfunkcją wielonarządową do późnoobjawowej adrenoleukodystrofii występującej u dorosłych, sprzężonej z chromosomem X. Dzięki zastosowaniu wysokospecjalistycznych technik analitycznych jest to stale powiększająca się grupa rzadkich chorób genetycznych.
\end{abstract}

\section{WPROWADZENIE}

Peroksysomy zostały po raz pierwszy opisane w 1954r przez Rodin'a, ale ich właściwości biochemiczne zdefiniował Christian de Duve w 1965 r, odkrywając w nich enzymy generujące nadtlenek wodoru [1,2]. Peroksysomy, jednobłonowe organelle są obecne prawie we wszystkich komórkach eukariotycznych. Komórki ssaków zawierają setki peroksysomów, przy czym najliczniej występują one w wątrobie, nerkach i tkance nerwowej. Ich liczba, morfologia i wielkość są regulowane w odpowiedzi na sygnały środowiska i stopnień rozwoju organizmu. Kształt i rozmiar $(\Phi 0,2-1 \mu \mathrm{m})$ jest zależny od rodzaju tkanki [3]. Oszacowano, że czas półtrwania dla peroksysomu wynosi w przybliżeniu około dwóch dni, co sugeruje, że peroksysomalna biogeneza, aktywność biochemiczna i degradacja są procesami bardzo dynamicznymi [4]. Początkowo nie doceniano ich znaczenia i sądzono, że to mało znaczące organelle, ewentualne prekursory mitochondrium lub lizosomów. Badania ostatnich lat wykazały, że peroksysomy to wielozadaniowe organelle, które w różnych tkankach i organizmach spełniają kluczową rolę w licznych procesach biochemicznych w metabolizmie komórki.

\section{BIOGENEZA I FUNKCJE PEROKSYSOMU}

W okresie ostatnich trzech dekadach, nastąpił ogromny postęp w badaniach nad peroksysomami na poziomie biochemicznym i molekularnym. Zidentyfikowano około 30 genów PEX kodujących peroksyny, czynniki białkowe niezbędne $\mathrm{w}$ procesie biogenezy peroksysomu. Badania prowadzone przez Lazarowa i Fujiki [5], stworzyły podstawę opracowania modelu biogenezy peroksysomu. Model ten zakłada autonomiczność struktury, a proces formowania obejmuje etapy wzrostu z preperoksysomów i następnie podziału dojrzałego organellum. Wykazano, że mRNA kodujące enzymy macierzy peroksysomu oraz peroksysomalne białka błonowe są tworzone na wolnych polirybosomach i importowane z cytosolu do peroksysomalnej błony lub macierzy [5]. Zależnie od spełnianych funkcji klasyfikujemy 3 rodzaje peroksyn, które uczestniczą odpowiednio w tworzeniu błony peroksysomalnej, macierzy peroksysomu i jego morfogenezie. Białka Pex3, Pex16 i Pex19 zostały zidentyfikowane jako czynniki uczestniczące w kształtowaniu błony peroksysomalnej u drożdży. Dziesięć peroksyn Pex1, Pex2, Pex5, Pex6, Pex7, Pex10, Pex12, Pex13, Pex14, Pex26 uczestniczy w mechanizmie translokacji zsyntetyzowanych białek macierzy do wnętrza organelli [6]. Pozostałe peroksyny biorą udział w morfogenezie peroksysomów. Są to trzy izoformy białka rodziny Pex 11, a- $\beta$ - $\gamma^{-}$, oraz białka DLP1 i Fis1, jak również mitochondrialny czynnik podziału (Mff, ang. mitochondrial fission factor) [7-9].

\section{Teresa J. Stradomska}

Zakład Biochemii i Medycyny Doświadczalnej, Instytut „Pomnik-Centrum Zdrowia Dziecka”

Zakład Biochemii i Medycyny Doświadczalnej, Instytut „Pomnik-Centrum Zdrowia Dziecka" Al. Dzieci Polskich 20,04730 Warszawa; tel.: (22) 81516 38, e-mail: jstradomska@op.pl

Artykuł otrzymano 24 czerwca 2018 r. Artykuł zaakceptowano 24 września 2018 r.

Słowa kluczowe: peroksysomy, choroby zaburzenia biogenezy peroksysomu, deficyt pojedynczego enzymu/białka transportowego, zespół Zellwegera, adrenoleukodystrofia, VLCFA

Wykaz skrótów: ccALD (ang. childhood cerebral $A L D)$ - dziecięca mózgowa postać $A L D$; DBP (ang. D-bifunctional protein) - białko dwufunkcyjne; DHA (ang. docosahexaenoic acid) - kwas dokozaheksaenowy; DPL-1 (ang. dynamin related protein) - białko podobne do dynaminy; ER (ang. endoplasmic reticulum) - siateczka endoplazmatyczna; MCS (ang. membrane contact site) - miejsce kontaktu błon; Mff (ang. mitochondrial fission factor) - mitochondrialny czynnik podziału; MRI (ang. magnetic resonance imaging) - rezonans magnetyczny; NGS (ang. next generation sequencing) - sekwencjonowanie następnej generacji; LO (ang. Lorenzo oil) - Olej Lorenzo"a; PBD (ang. peroxisomal biogenesis disorders) - choroby zaburzenia biogenezy peroksysomu; PMP (ang. peroxisomal membrane protein) - peroksysomalne białko błonowe; PTS (ang. peroxisome targeting signal) - odcinki sygnałowe białek peroksysomalnych; ROS (ang. reactive oxygen species) - reaktywne formy tle$\mathrm{nu}$; VLCFA (ang. very long chain fatty acids) bardzo długołańcuchowe kwasy tłuszczowe; WES (ang. whole-exome sequencing) - sekwencjonowanie całego eksomu; X-ALD (ang. X-linked adrenoleukodystrophy) - adrenoleukodystrofia sprzężona $\mathrm{z}$ chromosomem X; ZS (ang. Zellweger Syndrome) - zespół Zellwegera; ZSDs (ang. Zellweger spectrum disorders) - choroby spektrum zespołu Zellwegera

Podziękowania: Praca finansowana przez Instytut-Pomnik Centrum Zdrowia Dziecka ze środków przeznaczonych na naukę (S155/2017; S161/2017). 


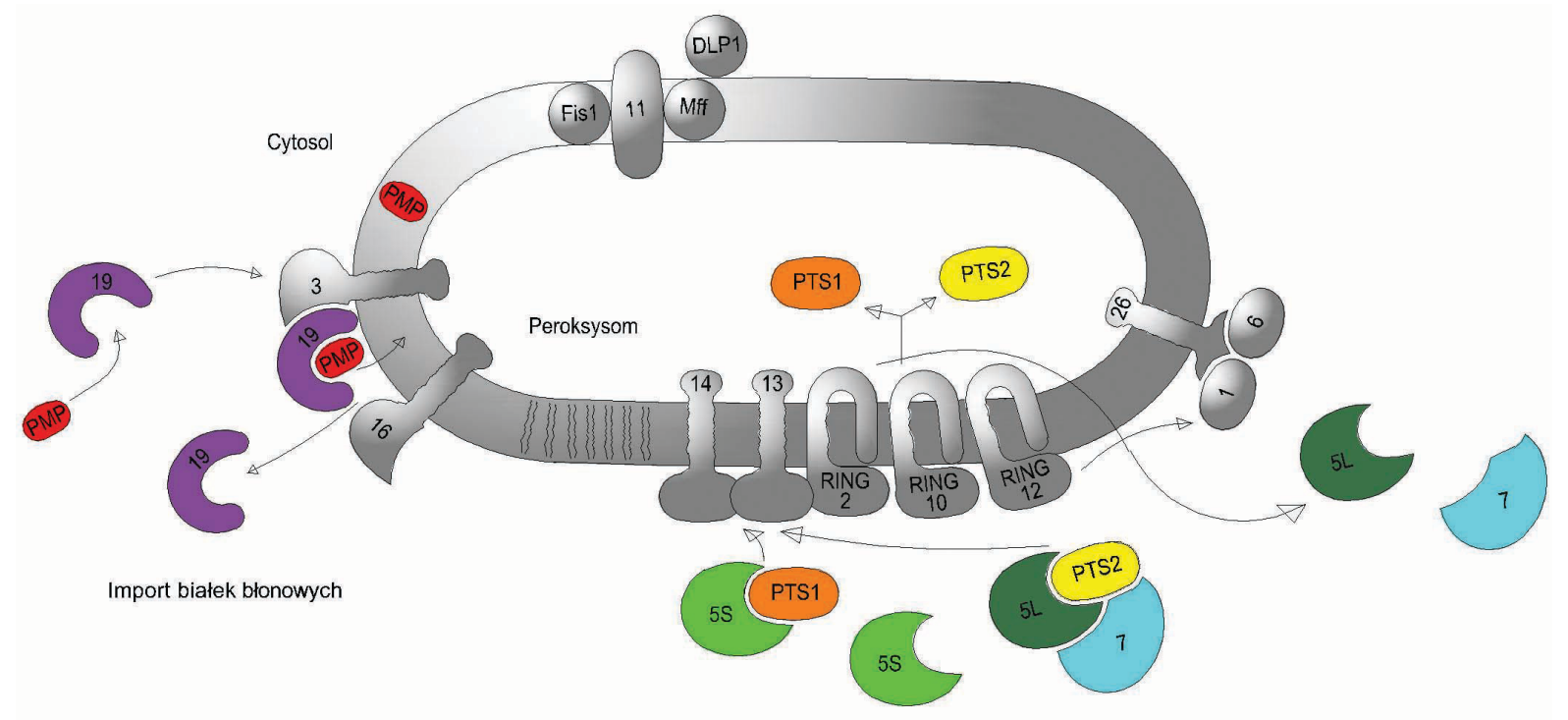

Import białek macierzy

Rycina 1. Schemat modelu importu białek błonowych i białek macierzy w peroksysomie. Objaśnienia w tekście.

Struktura peroksysomu u ssaków oparta jest o 16 genów PEX. Peroksysomalne białka błonowe (PMP, ang. peroxisomal membrane protein) wprowadzane są za pośrednictwem PEX19 działającego jako chaperon wiążący cytosolowe PMP, następnie powstały kompleks jest dokowany przez PEX3 w błonie peroksysomalnej. Białka macierzy peroksysomalnej zaraz po syntezie w cytosolu są transportowane przy udziale sygnałów kierunkowych PTS (ang. peroxisome targeting signal, PTS1 lub PTS2). Wahadłowe receptory cytosolowe PEX5 z dwiema domenami końcowymi C-(PEX5-S) i N-(PEX5-L) oraz PEX7 wychwytują białka macierzy i tworząc odpowiednie kompleksy PTS1-PEX5-S i PTS2-PEX5-L-PEX7 wprowadzają je do wnętrza organellum. Za pośrednictwem kompleksu PEX2-PEX10-PEX12 białka macierzy uwalniane są do wewnątrz, natomiast kompleks białek PEX26-1-6 pośredniczy w recyklingu receptorów do cytosolu [10,11] (Ryc. 1).

W ostatnich latach niektóre wyniki badań sugerują, że peroksysomy to jednak semi-autonomiczne organelle, których formowanie zapoczątkowane zostaje $\mathrm{w}$ siateczce endoplazmatycznej (ER) pod wpływem Pex3 i Pex16 $[12,13]$. Wykazano, że co najmniej kilka białek błonowych może być transportowanych do peroksysomu z udziałem ER $[14,15]$. Stwierdzono natomiast, że niektóre PMP są kierowane do peroksysomu zarówno bezpośrednio z cytosolu jak i za pośrednictwem ER [11,16-18]. Koncepcja ta nawiązuje do pierwotnej hipotezy tworzenia peroksysomu sformułowanej w latach 70. [19]. Mimo upływu lat i przeprowadzenia wielu prac badawczych do tej pory tworzenie peroksysomu wciąż pozostaje interesującym zagadnieniem. Prawdopodobnie obie teorie są prawdziwe. Badania prowadzone na drożdżach pozwalają wnioskować, że w normalnych warunkach peroksysomy są formowane przez kolejne etapy wzrostu i podziału, natomiast $\mathrm{w}$ sytuacji braku peroksysomów w komórce mogą być formowane z udziałem ER [20].

\section{FUNKCJE}

Analizy proteomiczne wykazują, że peroksysom to stosunkowo prosta, obejmująca około 100 białek struktura biochemiczna [21]. Mimo tej prostoty ma on kluczowe znaczenie dla rozwoju i zdrowia człowieka, co podkreśla unikalność i ilość procesów metabolicznych, w których uczestniczy oraz grupa chorób genetycznych, w których działanie peroksysomów jest całkowicie lub częściowo zaburzone.

Ponad 60 procesów biochemicznych katabolicznych jak $\mathrm{i}$ anabolicznych przebiega $\mathrm{w}$ peroksysomach. Ich rola fizjologiczna zmienia się zależnie od typu komórki, tkanki, stopnia rozwoju. Ta biochemiczna różnorodność jest możliwa dzięki dynamicznym właściwościom błony peroksysomalnej reagującej na aktualne wymogi stanu fizjologicznego komórki [22]. Główne funkcje peroksysomalne to funkcje odkryte najwcześniej, czyli procesy oksydacyjne i detoksyfikacja reaktywnych form tlenu.

$\mathrm{W}$ systemie peroksysomalnej $\beta$-oksydacji degradacji ulegają bardzo długołańcuchowe kwasy tłuszczowe (VLCFA, ang. very long- chain fatty acids,), 2-metylo-podstawione kwasy (kwas pristanowy, ang. prystanic acid), kwasy dwukarboksylowe, prekursory kwasów żółciowych (kwas trihydroksycholowy, THCA, ang. trihydroksycholestanoic acid i dihydroksycholowy, DHCA, ang. dihydroksycholestanoic acid). Szlak ten jest wykorzystywany $\mathrm{w}$ procesie degradacji leukotrienów oraz stanowi ostatni etap syntezy kwasu dokozaheksaenowego, DHA (ang. docosahexaenoic acid). Drugim procesem utleniania zlokalizowanym $\mathrm{w}$ peroksysomach jest a-oksydacja, podczas której zachodzi degradacja kwasu fitanowego. Pozostałe unikatowe procesy peroksysomalne to biosynteza eterofosfolipidów, racemizacja kwasu pristanowego i prekursorów kwasów żółciowych DHCA/THCA, detoksyfika- 
Tabela 1. Choroby peroksysomalne.

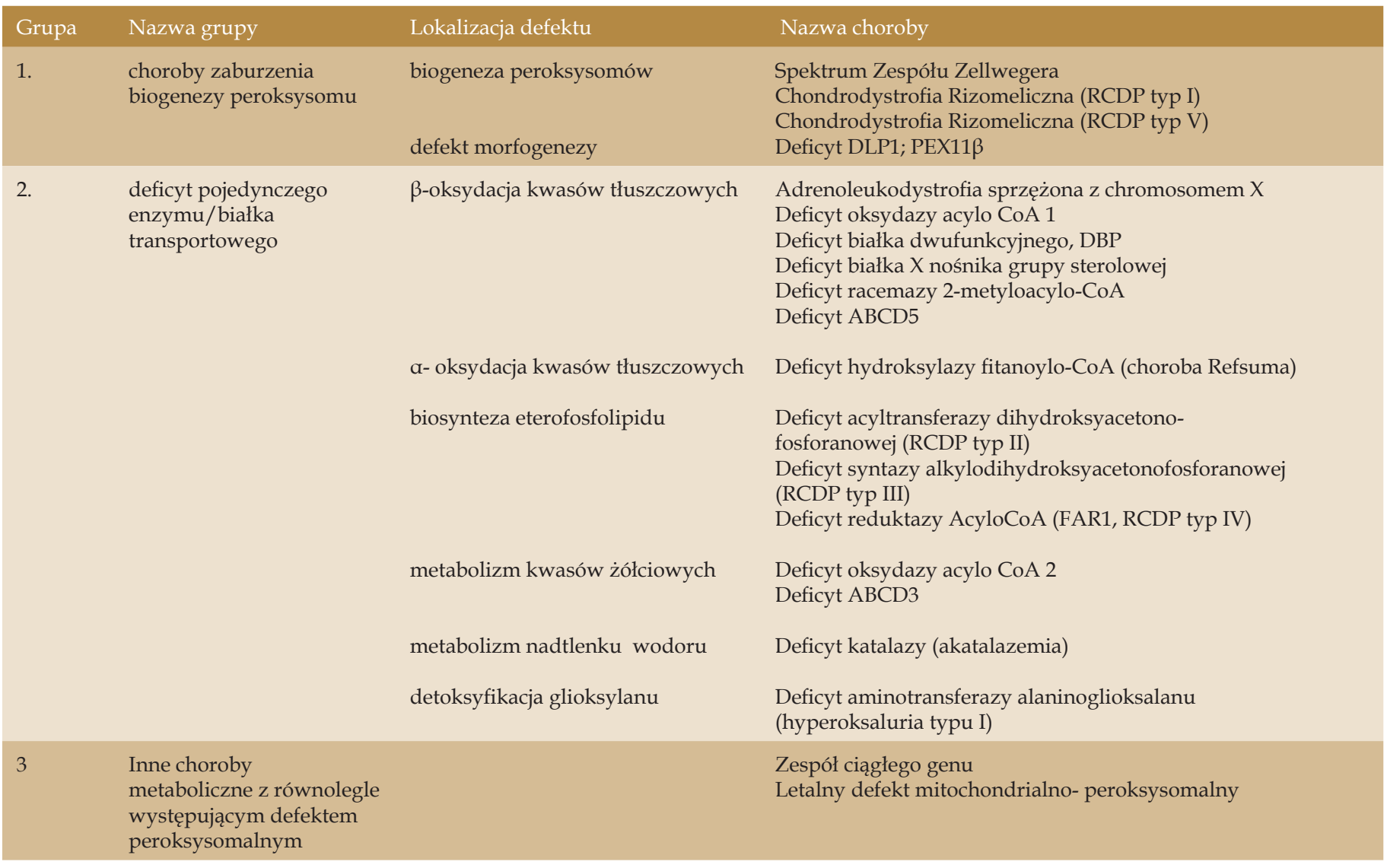

cja glioksalanu oraz nadtlenku wodoru. Procesy te szczegółowo były opisywane we wcześniejszych opracowaniach $[23,24]$. Analiza powyższych szlaków biochemicznych uwidacznia liczne związki między peroksysomami a innymi kompartmentami komórki. Chociaż wcześniej uważano, że peroksysomy spełniają autonomicznie swoje funkcje metaboliczne, głównie mając na uwadze produkcję i inaktywację nadtlenku wodoru i reaktywnych form tlenu (ROS, ang. reactive oxigen species) to obecnie odkrywając coraz więcej ich właściwości wiemy, że wypełniając swoje zadania biochemiczne muszą one integralnie współdziałać z innymi organellami komórkowymi. Synteza czy rozpad wielu skomplikowanych związków chemicznych przebiega wieloetapowo, a pojedyncze etapy są umiejscowione w różnych organellach subkomórkowych [24]. Peroksysomy współpracują z mitochondrium w degradacji kwasów tłuszczowych, detoksykacji glioksalanu, a z ER w procesie syntezy eterofosfolipidów, kwasów żółciowych. W lizosomach natomiast następuje uwalnianie kwasów tłuszczowych z rozbudowanych związków lipidowych, które następnie ulegają oksydacji w peroksysomach. Z kolei pewne białka jak np. czynniki podziału DLP1 i Mff są aktywne zarówno w mitochondriach jak i peroksysomach. Podobnie wykazano podwójną lokalizację (mitochondrium/peroksysom) dla niektórych enzymów [24,25]. Drogi komunikacyjne między poszczególnymi organellami są niezbędne do optymalizacji ich funkcji metabolicznych. Ostatnie dane wykazują, że dla przeprowadzenia pewnych procesów konieczne jest spojenie peroksysomu z ER. Białka błonowe związane z ER
(VAPA i VAPB) łączą się z peroksysomalnym białkiem błonowym ACBD5 unieruchamiając peroksysom tworzą miejsce kontaktu błon (MCS, ang. membrane contact site), w którym błony organelli zbliżają się, ale nie ulegają fuzji. W miejscach tych zachodzi wymiana jonów i lipidów. Interakcja ta wymagana jest dla procesu wzrostu organelli i utrzymania homeostazy lipidowej [26,27]. Podobne miejsca kontaktu błon obserwowano w układzie mitochondrium - peroksysom. Wymiana cząsteczek pomiędzy peroksysomami a innymi organellami może zachodzić z udziałem różnych mechanizmów, które pozostają $\mathrm{w}$ fazie badań. Sugeruje się, że jednym $\mathrm{z}$ nich jest transport pęcherzykowy [28].

\section{CHOROBY PEROKSYSOMALNE}

Zaburzenie struktury peroksysomu na poziomie biogenezy lub defektu pojedynczego enzymu stanowi podłoże patogenetyczne chorób peroksysomalnych. Choroby peroskysomalne obejmują dwie grupy, choroby będące skutkiem zaburzenia biogenezy peroksysomu (PBD, ang. peroxisomal biogenesis disorders) oraz deficyt pojedynczego białka peroksysomalnego (SED, ang. single enzyme deficiencies) (Tab. 1). PBD spowodowane są mutacją w co najmniej jednym z 14 genów $P E X$, najliczniej mutacje występują w genach PEX1 - 60\%, PEX6 - 16\% i PEX12 - 7\%. Pierwszą chorobą peroksysomalną opisaną przez Zellwegera był letalny zespół mózgowo-wątrobowo-nerkowy, obecnie określany jako klasyczny zespół Zellwegera (ZS, ang. Zellweger Syndrom). Choroby zaburzenia biogenezy 
peroksysomu klasyfikowane są w dwóch podgrupach: choroby spektrum zespołu Zellwegera (ZSDs, ang. Zellweger spectrum disorders) i chondrodystrofia rizomeliczna (RCDP, ang. rhizomelic chondrodysplasia punctata) typu I. Objawy kliniczne występujące $\mathrm{u}$ chorych to dysmorfia twarzowoczaszkowa, nieprawidłowości w budowie szkieletu, hepatomegalia, dysfunkcja wątroby, uszkodzenie oczu i słuchu, niewydolność kory nadnerczy, wrodzone wady serca, uszkodzenie nerek. Większość procesów metabolicznych przebiegających w peroksysomach dotyczy związków lipidowych, niezbędnych w procesie tworzenia i funkcjonowania układu nerwowego stąd większości chorób towarzyszą objawy neurologiczne, w tym encefalopatia, dysmielinizacja, hipotonia mięśniowa, neuropatia, napady padaczkowe oraz opóźnienie rozwoju psychoruchowego [3,29].

W przeważającej większości chorzy z PBD prezentują klasyczny ZS. Obecnie, dzięki większej wiedzy klinicystów jak i łatwiejszemu dostępowi do wysokospecjalistycznych technik diagnostycznych pojawiły się opisy pacjentów późno objawowych z ZSDs. Szczególnie pacjenci z postacią młodzieńczą lub występującą u dorosłych są trudni do zdiagnozowania. W tej grupie występuje duża heterogenność symptomów, chorzy mogą mieć dysmorfię lub nie, a opóźnienie rozwoju może ujawnić się w różnym stopniu lub być niezauważalnym [30].

Chondrodystrofia rizomeliczna występuje z częstotliwością 1:100000. Większość pacjentów ma defekt $\mathrm{w}$ PEX7 (RCDP1), pozostałe postaci choroby związane są z uszkodzeniem enzymów uczestniczących w syntezie plazmalogenu (GNPAT, AGPS, FAR1) [31]. Obraz kliniczny RCDP typu 1-3 jest na ogół ciężki, charakteryzuje się anomalią szkieletu, uszkodzeniem wzroku, opóźnieniem psychoruchowym. Najcięższą postać prezentują pacjenci $\mathrm{z}$ niewielkim lub zerowym poziomem plazmalogenu, $\mathrm{u}$ których obserwowano zmiany w mielinie i atrofię móżdżku. Opisywano również pacjentów o łagodnej postaci z obniżonym poziomem plazmalogenu [32].

Najczęściej występującą chorobą peroksysomalną jest adrenoleukodystrofia sprzężona $\mathrm{z}$ chromosomem $\mathrm{X}(\mathrm{X}$ -ALD, ang. X-linked adrenolekodystrophy) z częstością występowania 1:17 000 [33]. Jest to postępująca choroba neurodegeneracyjna, spowodowana defektem genu kodującego błonowe białko transportowe ABCD1 dostarczające VLCFA do peroksysomu. Uszkodzenie procesu peroksysomalnej $\beta$-oksydacji na etapie transportu powoduje kumulację VLCFA w tkankach i płynach ustrojowych. Choroba występuje w kilku fenotypach klasyfikowanych zależnie od wieku zachorowania, symptomatologii i szybkości progresji. Dwa najczęstsze fenotypy to najcięższa letalna postać mózgowa dziecięca ( $c c A L D$, ang. childhood cerebral $A L D)$ z objawami pojawiającymi się we wczesnym okresie dzieciństwa (4-8 roku życia) i najłagodniejsza adrenomieloneuropatia (AMN) w której demonstracja objawów występuje głównie w 3-ciej i 4- tej dekadzie życia i obejmuje obwodowy układ nerwowy. W prowadzonych badaniach molekularnych nie wykazano korelacji genotyp-fenotyp [34,35].
Drugim najczęściej występującym zaburzeniem peroksysomalnej $\beta$-oksydacji jest niedobór białka dwufunkcyjnego (DBP, ang. D-bifunctional protein deficiency), który w formie klinicznej przypomina ZS z dysmorfią twarzowo-czaszkową, migracją neuronów oraz krótkim okresem przeżycia. Białko DBP, określane również jako białko MFP2 (ang. multifunctional protein-2), wykazuje dwie aktywności katalityczne jako hydrataza 2-enoilo-CoA i dehydrogenaza (3R)-hydroksyacyl-CoA, co warunkuje trzy różne typy funkcji niedoboru DBP, przy czym najcięższym jest deficyt obu aktywności enzymu. Ostatnio opisano jednak postaci choroby charakteryzujące się bardzo łagodnym przebiegiem, co rozszerza perspektywę klinicznych manifestacji niedoboru DBP $[29,36]$.

Choroby peroksysomalne należą do grupy chorób rzadkich. W oparciu o analizę wyników z badań diagnostycznych chorób peroksysomalnych prowadzonych $\mathrm{w}$ IPCZD dla obszaru całego kraju, oszacowano częstość występowania chorób peroksysomalnych w populacji polskiej. I tak zaburzenia biogenezy peroksysomu występują w liczbie 0,20 przypadków na 100000 urodzeń. Natomiast częstość występowania X-ALD/AMN w Polsce wynosi 2,9 przypadków na 100000 żywo urodzonych chłopców. Dane te pokrywają się z danymi z innych światowych ośrodków medycznych [34].

\section{NOWOODKRYTE CHOROBY PEROKSYSOMALNE}

\section{NIEDOBÓR OKSYDAZY ACYLO-COA 2}

Oksydaza acylo-CoA 2 jest jedną z dwóch różnych oksydaz acyloCoA związanych ze szlakiem peroksysomalnej $\beta$-oksydacji. W 2016 roku opisano dwóch pacjentów, u których stwierdzono deficyt oksydazy acylo-CoA 2. Chorzy wykazywali zaburzenia hepatologiczne, ataksję i upośledzenie funkcji poznawczych. Analizy biochemiczne wykazywały podwyższone poziomy transaminaz i wysokie stężenie kwasów żółciowych [37]. Oksydaza acylo-CoA 2 została zidentyfikowana w peroksysomach wątroby, uczestniczy ona specyficznie w reakcjach degradacji kwasów łłuszczowych o rozgałęzionych łańcuchach, w tym kwasu pristanowego i prekursorów kwasów żółciowych (THCA, DHCA).

\section{NIEDOBÓR BIAŁKA ABCD3}

Białko ABCD3, znane również jako PMP70, jest błonowym białkiem transportowym należącym do rodziny białkowych transporterów błonowych ABC z kasetą wiążącą ATP zaangażowanym w transport substratów białkowych do wnętrza peroksysomu. Opisano pacjenta z hepatosplenomegalią, znaczną niewydolnością wątroby, $\mathrm{u}$ którego analiza biochemiczna wykazała kumulację kwasów di- i tri-hydroksycholestanowych. Przeprowadzona analiza molekularna wykazała defekt w genie kodującym ABCD3 [38].

\section{NIEDOBÓR BIAŁKA ACBD5}

ACBD5 to perosysomalne białko błonowe z N-końcową domeną wiążącą skierowaną do cytosolu. Wcześniej- 
Tabela 2. Markery biochemiczne w diagnostyce chorób peroksysomalnych.

\begin{tabular}{|c|c|c|c|c|c|c|}
\hline $\begin{array}{l}\text { Choroba } \\
\text { peroksysomalna }\end{array}$ & VLCFA & $\begin{array}{l}\text { Kwas } \\
\text { fitanowy }\end{array}$ & $\begin{array}{l}\text { Kwas } \\
\text { pristanowy }\end{array}$ & Plazmalogen & $\begin{array}{l}\text { DHCA/ } \\
\text { THCA }\end{array}$ & Gen \\
\hline ZSD & $\uparrow \uparrow$ & $\mathrm{N}-\uparrow$ & $\mathrm{N}-\uparrow$ & $\downarrow N$ & $\uparrow$ & PEX 1,2,3,5,6,10, 12, 13,14,16,19,26 \\
\hline RCDP I & $\mathrm{N}$ & $\mathrm{N}-\uparrow$ & $\mathrm{N}$ & $\downarrow$ & $\mathrm{N}$ & PEX 7 \\
\hline X-ALD & $\uparrow$ & $\mathrm{N}$ & $\mathrm{N}$ & $\mathrm{N}$ & $\mathrm{N}$ & $A B C D 1$ \\
\hline ACOX1 & $\uparrow$ & $\mathrm{N}$ & $\mathrm{N}$ & $\mathrm{N}$ & $\mathrm{N}$ & ACOX1 \\
\hline DBP & $\uparrow$ & $\uparrow-\mathrm{N}$ & $\uparrow-\mathrm{N}$ & $\mathrm{N}$ & $\uparrow-\mathrm{N}$ & 17HSDB4 \\
\hline SCPx & $\mathrm{N}$ & $\uparrow-\mathrm{N}$ & $\uparrow$ & $\mathrm{N}$ & $\uparrow$ & $S C P 2$ \\
\hline AMACR & $\mathrm{N}$ & $\uparrow-\mathrm{N}$ & $\uparrow^{*}$ & $\mathrm{~N}$ & $\uparrow$ & $A M A C R$ \\
\hline RCDP II & $\mathrm{N}$ & $\mathrm{N}-\uparrow$ & $\mathrm{N}$ & $\downarrow$ & $\mathrm{N}$ & GNPAT \\
\hline RCDP III & $\mathrm{N}$ & $\mathrm{N}-\uparrow$ & $\mathrm{N}$ & $\downarrow$ & $\mathrm{N}$ & AGPS \\
\hline Hyperoksaluria & $\mathrm{N}$ & $\mathrm{N}$ & $\mathrm{N}$ & $\mathrm{N}$ & $\mathrm{N}$ & $A G X T$ \\
\hline Alcatalazemia & $\mathrm{N}$ & $\mathrm{N}$ & $\mathrm{N}$ & $\mathrm{N}$ & $\mathrm{N}$ & $C A T$ \\
\hline
\end{tabular}

ZSD - Spektrum Zespółu Zellwegera; RCDP I - chondrodystrofia rizomeliczna typ I; X-ALD - adrenoleukodystrofia; ACOX1 - deficyt oksydazy acylo CoA; DBP - deficyt białka dwufunkcyjnego; SCPx - deficyt białka X nośnika grupy sterolowej; AMACR - deficyt racemazy 2-metyloacylo-CoA; RCDP II - deficyt acylotransferazy dihydroksyacetonofosforanowej; RCDP III - deficyt syntazy alkilodihydroksyacetonofosforanowej; VLCFA - bardzo długołańcuchowe kwasy tłuszczowe; DHCA/THCA - metabolity kwasów żółciowych; N - poziomy normalne; $\uparrow$ - poziomy podwyższone; $\downarrow$ - poziomy obniżone; Tab. wg Stradomska TJ [23] zmodyfikowana.

sze analizy proteomiczne ustaliły jego lokalizację w peroksysomach wątroby szczura i człowieka. W ostatnim okresie opisano niedobór tego białka u jednego pacjenta z postępującą leukodystrofią, rozszczepieniem podniebienia, ataksją i dystrofią nerek. Z parametrów biochemicznych wykazano jedynie podwyższone poziomy VLCFA. Rola jaką spełnia w metabolizmie komórkowym ACBD5 nie jest do końca wyjaśniona, wiadomo, że działa ono jako receptor wiążący dla VLCFA-CoA, i wstępuje w interakcje z VAPB, białkiem związanym z ER uczestnicząc $\mathrm{W}$ powstawaniu miejsc kontaktu błon ER - peroksysom $[39,40]$.

\section{DIAGNOSTYKA CHORÓB PEROKSYSOMALNYCH}

Tak naprawdę historia chorób peroksysomalnych zaczęła się w 1973 roku, gdy Goldfisher wykazał morfologicznie brak peroksysomów w hepatocytach i komórkach kanalików nerkowych u pacjentów z ZS. Następnie w latach 80. zostały opublikowane dwie kluczowe prace, które wykazały podwyższone poziomy VLCFA i deficyt plazmalogenu u pacjentów z ZS. Te trzy odkrycia stanowiły podstawę do dalszych szczegółowych badań funkcji tych organelli $\mathrm{w}$ metabolizmie komórki i jednocześnie pozwoliły ukierunkować diagnostykę chorób peroksysomalnych na poziomie biochemicznym [41-43].

Diagnostyka chorób peroksysomalnych prowadzona jest na bazie detekcji związków zidentyfikowanych jako markery biochemiczne (Tab. 2). Głównym markerem biochemicznym dla tej grupy chorób rzadkich są bardzo długołańcuchowe kwasy tłuszczowe. VLCFA (> C22:0, C24:0, C26:0) są kwasami ulegającymi degradacji wyłącznie w systemie peroksysomalnej $\beta$-oksydacji. Uszkodzenie tego procesu prowadzi do nagromadzenia VLCFA w tkankach i płynach ustrojowych. Identyfikacja podwyższonych poziomów VLCFA, jako C24:0/C22:0, C26:0/C22:0 w surowicy metodą analizy instrumentalnej wskazuje na zaburzenie procesu peroksysomalnej $\beta$-oksydacji [24]. Detekcja podwyższonych poziomów VLCFA w surowicy lub plazmie jest podstawowym kryterium diagnostycznym w diagnostyce zaburzeń biogenezy peroksysomu (zespół Zellwegera), niedoboru pojedynczego enzymu czy białka transportowego. Podstawa wiarygodnej diagnostyki biochemicznej to dobrze opracowane wartości przedziałów referencyjnych [34]. Znajomość czynników klinicznych, żywieniowych i terapeutycznych wpływających na labilność określonego biomarkera chemicznego zwiększa jego wiarygodność diagnostyczną. Bardzo częstym objawem klinicznym obserwowanym u pacjentów z chorobą peroksysomalną jest padaczka. $W$ przypadkach postaci lekoopornej często stosowana jest dieta ketogenna. Wykazano, że dieta ketogenna nie zaburza wartości diagnostycznej parametrów VLCFA [44]. Drugim znamiennym kryterium klinicznym w grupie pacjentów z zaburzeniem działania pojedynczego enzymu lub biogenezy peroksysomu są zaburzenia funkcji wątroby. Analiza poziomów VLCFA u chorych $\mathrm{z}$ niewydolnością wątroby o podłożu innym, niż choroba peroksysomalna, wykazała podwyższenie wartości oznaczanych parametrów co wskazuje, że zaburzenie funkcji wątroby o innej etiologii niż defekt peroksysomu może generować wyniki fałszywie dodatnie [44].

Bazując na wartościach poziomów VLCFA w grupie hemi- i heterozygot X-ALD/AMN oraz $\mathrm{w}$ grupie kontrolnej wykazano, że optymalne różnicowanie diagnostyczne $\mathrm{w}$ diagnostyce chorób peroksysomalnych uzyskujemy 
analizując 5 parametrów VLCFA (C24:0/C22:0, C26:0/ C22:0, C22:0, C24:0, C26:0) [45].

Diagnostyka chorób peroksysomalnych prowadzona w IPCZD pozwoliła na opracowanie wartości przedziałów referencyjnych poziomów VLCFA dla chorób zaburzenia biogenezy peroksysomu, defektu pojedynczego enzymu peroksysomalnego oraz hemi- i heterozygot adrenoleukodystrofii sprzężonej $\mathrm{z}$ chromosomem $\mathrm{X}$ w populacji polskiej [34]. Analiza VLCFA może być stosowana $\mathrm{w}$ metodzie skrinningu rodzinnego $\mathrm{w}$ celu identyfikacji potencjalnych chorych $\mathrm{w}$ rodzinie. Została ona również użyta do oceny zdolności prokreacyjnych mężczyzn z adrenomieloneuropatią, późną postacią X-ALD. Badania wykazały, że wskaźnik oceny zaburzenia zdolności prokreacyjnych mężczyzn z AMN jest niewiele wyższy od wykazywanej niepłodności par w Polsce [46].

Na obecnym etapie wiedzy szczegółowy mechanizm patogenezy chorób peroksysomalnych nie jest znany. Przyjmuje się, że VLCFA są głównym czynnikiem sprawczym odpowiedzialnym za neurodegenerację układu nerwowego. Kumulacja VLCFA w organizmie powoduje zmiany morfologiczne, głównie $w$ błonie komórkowej oraz w strukturze mieliny. W badaniach in vitro wykazano toksyczny wpływ VLCFA na komórki nerwowe [47]. To jest zgodne z badaniami wykazującymi silną korelację $\left(r^{2}=0,822\right)$ poziomu kwasu cerotowego $(\mathrm{C} 26: 0)$ ze stopniem ciężkości choroby $\mathrm{w}$ grupie chorych $\mathrm{z}$ zaburzeniem biogenezy peroksysomu [34].

Drugim ważnym markerem stosowanym w diagnostyce chorób peroksysomalnych jest kwas fitanowy (PhA, ang. phytanic acid). PhA podlega degradacji $\mathrm{w}$ procesie peroksysomalnej a-oksydacji. Deficyt hydroksylazy fitanoiloCoA prowadzi do akumulacji PhA w tkance nerwowej. Parametr ten jest głównym biomarkerem w diagnostyce choroby Refsuma. Związek pochodzi wyłącznie ze źródeł egzogennych i jako parametr biochemiczny jest zależny od stosowanej diety co powoduje, że jest markerem mało stabilnym.

Peroksysomy są miejscem formowania wiązania eterowego w syntezie plazmalogenu, głównego czynnika lipidowego struktury błon cytoplazmatycznych i komórek tkanki nerwowej. W diagnostyce chorób peroksysomalnych deficyt tego biomarkera stwierdzamy w ciężkich postaciach klinicznych ZSDs i RCDP.

W ostatnim okresie opracowano oznaczanie C26:0 lysofosfatydylocholiny w suchej kropli krwi metodą tandemowej spektrometrii mas (LC-MS/MS). Umożliwiło to wprowadzenie tej nowej procedury jako metody w badaniu przesiewowym w kierunku X-ALD [48]. Dla potwierdzenia diagnozy $w$ przypadku wyników pozytywnych konieczne jest ilościowe oznaczenie poziomów VLCFA w surowicy.

Coraz częściej jako pierwszy test $\mathrm{w}$ procesie diagnostycznym u pacjentów z klinicznym podejrzeniem choroby peroksysomalnej lub innych chorób z grupy wrodzonych wad metabolizmu wybierana jest analiza moleku- larna polegająca na sekwencjonowaniu całego eksomu, WES (ang. whole exome sequencing), sekwencjonowaniu całego genomu, WGS (ang. whole genome sequencing) czy sekwencjonowaniu nowej generacji NGS (ang. next-generation sequencing). Badania przeprowadzone przez Ghosh'a wykazują, że wprowadzenie NGS do algorytmu diagnostycznego dla chorób rzadkich poprawia dokładność i szybkość procesu diagnostycznego [49]. W wypadku otrzymania pozytywnych wyników z zasady należy przeprowadzić analizę biochemiczną $\mathrm{w}$ celu sprawdzenia czy znalezione mutacje są przyczyną choroby [50].

\section{LECZENIE}

Chociaż obecnie nie są znane skuteczne metody leczenia chorób peroksysomalnych, to jednak podejmowane są próby leczenia czy też opóźnienia wystąpienia pierwszych objawów, jak w wypadku X-ALD. Działanie terapeutyczne prowadzi do normalizowania parametrów biochemicznych, w tym wyrównywania niewydolności kory nadnerczy. Postępowanie dietetyczne polega na eliminacji metabolitów kumulowanych i uzupełnianiu deficytowych. Jednakże VLCFA jest głównie pochodzenia endogennego i sama dieta nie jest wystarczająca [51,52].

\section{CHOROBY PBD}

Prowadzenie pacjenta $\mathrm{z}$ chorobą $\mathrm{z}$ grupy PBD obejmuje regularne badania neurologiczne, badania słuchu, wzroku jak również monitorowanie czynności wątroby i nadnerczy. Próby leczenia skupiają się generalnie na interwencjach dietetycznych. Jednakże raporty dotyczą często pojedynczych pacjentów lub małej grupy chorych, a prezentowane wyniki są rozbieżne odnośnie korzyści klinicznych. Pacjent z klasyczną postacią ZS był prowadzony na mieszance zawierającej GTO (oleinian trójglicerolu) z wykluczeniem VLCFA przez okres kilku miesięcy. Obserwowano obniżenie poziomu VLCFA o około 50\%, pomimo tego chłopiec zmarł w wieku 12 miesięcy [53].

Suplementacja DHA u pacjentów z PBD prowadzi do niejednoznacznych wyników i opisywane są rozbieżne skutki kliniczne. Pierwsze doniesienia, badań prowadzonych przez Martinez, były bardzo optymistyczne i sugerowały poprawę neurologiczną. Jednakże Paker $\mathrm{w}$ przeprowadzonych badaniach randominizowanych stwierdził, że co prawda podaż DHA podnosi jego poziom $\mathrm{w}$ plazmie, ale nie obserwujemy poprawy funkcji klinicznych [54,55].

Ostatnie wyniki badań, w grupie pacjentów z ZSDs, u których zastosowano suplementację diety kwasem cholowym w celu zmniejszenia syntezy prekursorów kwasów żółciowych, potwierdzają obniżenie poziomów DHCA i THCA. Niestety, równocześnie wykazują, że metoda nie może być stosowana $\mathrm{w}$ grupie pacjentów $\mathrm{z}$ poważną dysfunkcją wątroby ze względu na silny efekt toksyczny, co ogranicza jej zastosowanie jedynie do łagodnych postaci ZSDs [56].

Natomiast kwas fitanowy pochodzi wyłącznie ze źródeł egzogennych, stąd zastosowanie diety eliminacyjnej 
powoduje normalizację poziomu tego biomarkera w surowicy i co najważniejsze koresponduje z poprawą funkcji neurologicznych $[57,58]$.

\section{ADRENOLEUKODYSTROFIA}

Olej Lorenzo"a (LO) czyli mieszanina estrów glicerolu kwasu oleinowego i erukowego w połączeniu z dietą ograniczającą spożycie tłuszczy normalizuje poziom VLCFA w surowicy, ale nie zatrzymuje progresji choroby. Natomiast u pacjentów bezobjawowych zapobiega wystąpieniu formy mózgowej i opóźnia aktywację objawów [59]. Przeprowadzona analiza stężenia wzorca biomarkera podczas podaży LO wykazała, że wraz z obniżeniem nasyconych bardzo długołańcuchowych kwasów tłuszczowych następuje podwyższenie poziomu kwasów nienasyconych VLCFA [30].

Przeszczep szpiku (HSCT, ang. haematopoietic stem cell transplantation) jest stosowny jako metoda $\mathrm{z}$ wyboru $\mathrm{u}$ osób z mózgową formą X-ALD we wczesnym stadium choroby, z niewielkimi zmianami w obrazie MRI mózgu (<8 pkt w skali Loes'a). Ostatnie opracowania wykazują pozytywne wyniki (zatrzymanie procesu demielinizacji) przy śmiertelności $\mathrm{w}$ granicach $5-20 \%[60,61]$. W przypadku przyjęcia przeszczepu wykazano, że poziom VLCFA obniża się do poziomu odpowiedniego dla heterozygot X-ALD/AMN w czasie 8-12 miesięcy po transplantacji [34].

Obiecujące wyniki uzyskano stosując terapię genową. Transplantacje $\mathrm{z}$ autologicznym szpikiem kostnym transfekowanym in vitro genem $A B C D 1$ przeprowadzono u dwóch pacjentów. Uzyskano w ten sposób stabilizację skorygowanej syntezy białka ABCDP w granulocytach po 16 miesiącach oraz cofnięcie demielinizacyjnych zmian zapalnych $w$ mózgu. Obecnie procedura jest $w$ fazie badań klinicznych [62]. Doświadczenia wykazują, że VLCFA jest labilnym, dynamicznym biomarkerem, którego monitorowanie pozwala na ocenę efektów stosowanej terapii zarówno podczas stosowanej terapii dietetycznej jak i HSCT [63].

\section{PODSUMOWANIE}

W ostatnich latach nastąpił znaczny postęp w zakresie poznania roli peroksysomów $\mathrm{w}$ rozwoju i zdrowiu człowieka. Łatwiejszy dostęp do wysokospecjalistycznej diagnostyki metabolicznej sprawia, że rozpoznajemy coraz więcej wrodzonych wad metabolicznych w tym, chorób peroksysomalnych, nawet o łagodnej postaci. Szybki postęp technologiczny przyspiesza diagnostykę i umożliwia identyfikację nowych biomarkerów, nowych chorób i nowych fenotypów. Stwarza to podstawy poznania szczegółowej patogenezy chorób peroksysomalnych, co powinno przyczynić się do opracowania skutecznych metod leczenia, których obecnie brak.

\section{PIŚMIENNICTWO}

1. Rhodin J (1954) Correlation of ultrastructural organization and function in normal and experimentally changed peroxisomal convoluted tubule cells of the mouse kidney. phD-thesis, Aktiebolaget Godvil, Stockholm
2. de Duve C, Baudhuin P (1966) Peroxisomes (microbodies and related particles). Physiol Rev 46: 323-357

3. Braverman NE, D'Agostino MD, Maclean GE (2013) Peroxisome biogenesis disorders: Biological, clinical and pathophysiological perspectives. Dev Disabil Res Rev 17: 187-196

4. Anding AL, Baehrecke EH (2017) Cleaning House: Selective Autophagy of Organelles. Dev Cell 41: 10-22

5. Lazarow PB, Fujiki Y (1985) Biogenesis of peroxisomes. Annu Rev Cell Biol 1: 489-530

6. Fujiki Y (2000) Peroxisome biogenesis and peroxisome biogenesis disorders. FEBS Lett 476: 42-46

7. Thoms S, Erdmann R (2005) Dynamin-related proteins and Pex11 proteins in peroxisome division and proliferation. FEBS J 272: 5169-5181

8. Fujiki Y, Itoyama A, Abe Y, Honsho M (2014) Molecular complex coordinating peroxisome morphogenesis in mammalian cells. W: Brocard C, Hartig A (red) Molecular Machines Involved in Peroxisomes Maintenance. Springer-Verlag, Berlin, 391-401

9. Hua R, Kim PK (2016) Multiple paths to peroxisomes: Mechanism of peroxisome maintenance in mammals Biochim Biophys Acta 1863 881-891

10. Kim PK, Hettema EH (2015) Multiple pathways for protein transport to peroxisomes. J Mol Biol 427: 1176-1190

11. Liu Y, Yagita Y, Fujiki Y (2016) Assembly of peroxisomal membrane proteins via the direct Pex19p-Pex3p pathway. Traffic 17: 433-455

12. Hua R, Gidda SK, Aranovich A, Mullen RT, Kim PK (2015) Multiple domains in PEX16 mediate its trafficking and recruitment of peroxisomal proteins to the ER. Traffic 16: 832-852

13. Kim PK, Mullen RT, Schumann U, Lippincott-Schwartz J (2006) The origin and maintenance of mammalian peroxisomes involves a de novo PEX16-dependent pathway from the ER. J Cell Biol 173: 521-532

14. Agrawal G, Joshi S, Subramani S (2011) Cell-free sorting of peroxisomal membrane proteins from the endoplasmic reticulum. Proc Natl Acad Sci USA 108: 9113-9118

15. Yonekawa S, Furuno A, Baba T, Fujiki Y, Ogasawara Y, Yamamoto A, Tagaya M, Tani K (2011) Sec16B is involved in the endoplasmic reticulum export of the peroxisomal membrane biogenesis factor peroxin 16 (Pex16) in mammalian cells. Proc Natl Acad Sci USA 108: 12746-12751

16. Matsuzono Y, Fujiki Y (2006) In vitro transport of membrane proteins to peroxisomes by shuttling receptor Pex19p. J Biol Chem 281: 36-42

17. Aranovich A, Hua R, Rutenberg AD, Kim PK (2014) PEX16 contributes to peroxisome maintenance by constantly trafficking PEX3 via the ER. J Cell Sci 127: 3675-3686

18. Mayerhofer PU, Bañó-Polo M, Mingarro I, Johnson AE (2016) Human peroxin PEX3 is cotranslationally integrated into the ER and exits the ER in budding vesicles. Traffic 17: 117-130

19. Novikoff PM, Novikoff AB (1972) Peroxisome in absorptive cells of mammalian small intestine. J Cell Biol 53: 532-560

20. Motley AM, Hettema EH (2007) Yeast peroxisomes multiply by growth and division. J Cell Biol 178: 399-410

21. Islinger M, Grille S, Fahimi HD, Schrader M (2012) The peroxisome: an update on mysteries. Histochem Cell Biol 137: 547-574

22. Platta HW, Erdmann R (2007) Peroxisomal protein import machinery. FEBS Lett 581: 2811- 2819

23. Wanders RJA (2014) Metabolic functions of peroxisomes in health and disease. Biochimie 98: 36-44

24. Stradomska TJ (2011) Peroksysomy - funkcje i zaburzenia metaboliczne. Postepy Biochem 57: 183-190

25. Thoms S, Grønborg S, Gärtner J (2009) Organelle interplay in peroxisomal disorders. Trends Mol Med 15: 293-302

26. Costello JL, Castro IG, Hacker C, Schrader TA, Metz J, Zeuschner D, Azadi AS, Godinho LF, Costina V, Findeisen P, Manne A, Islinger M, Schrader M (2017) ACBD5 and VAPB mediate membrane associations between peroxisomes and the ER. J Cell Biol 216: 331-342

27. Hua R, Cheng D, Coyaud E, Freeman S, Di Pietro E, Wang Y, Vissa A, Yip CM, Fairn GD, Braverman N, Brumell JH, Trimble WS, Raught B, 
Kim PK (2017) VAPs and ACBD5 tether peroxisomes to the ER for peroxisome maintenance and lipid homeostasis. J Cell Biol 216: 367-377

28. Neuspiel M, Schauss AC, Braschi E, Zunino R, Rippstein P, Rachubinski RA, Andrade-Navarro MA, McBride HM (2008) Cargo-selected transport from the mitochondria to peroxisomes is mediated by vesicular carriers. Curr Biol 18: 102-108

29. Stradomska TJ (2010) Choroby peroksysomalne. Pediatr Pol 85: 148155

30. Rydzanicz M, Stradomska T, Jurkiewicz E, Jamroz E, Gasperowicz P, Kostrzewa G, Płoski R, Tylki-Szymańska A (2017) Mild Zellweger syndrome due to a novel PEX6 mutation: correlation between clinical phenotype and in silico prediction of variant pathogenicity. J Applied Genet 58: 475-48

31. Bams-Mengerink AM, Koelman JH, Waterham H, Barth PG, Poll-The BT (2013) The neurology of rhizomelic chondrodysplasia punctata. Orphanrt J Rare Dis 8: 174

32. Bams-Mengerink AM, Majoie CB, Duran M, Wanders RJ, van Hove J, Scheurer CD, Barth PG, Poll-The BT (2006) MRI of the brain and cervical spinal cord in rhizomelic chondrodysplasia punctata. Neurology 66: 798-803

33. Bezman L, Moser AB, Raymond GV, Rinaldo P, Watkins PA, Smith KD, Kass NE, Moser HW (2001) Adrenoleukodystrophy: incidence, new mutation rate, and results of extended family screening. Ann Neurol 49: 512-517

34. Stradomska TJ, Tylki-Szymańska A (2009) Serum VLCFA levels determined by gas chromatography in the diagnosis of peroxisomal disorders. Folia Neuropathol 47: 306-313

35. Zgorzalewicz-Stachowiak M, Stradomska TJ, Bartkowiak Z, Galas-Zgorzalewicz B (2006) Cerebral childhood and adolescent X-linked adrenoleukodystrophy. Clinical presentation, neurophysiological, neuroimaging and biochemical investigations. Folia Neuropathol 44: 319-326

36. Paprocka J, Jamroz E, Adamek D, Stradomska TJ, Głuszkiewicz E, Grzybowska-Chlebowczyk U, Marszał E (2007) Clinical and neuropathological picture of familial encephalopathy with bifunctional protein deficiency. Folia Neuropathol 45: 213-219

37. Vilarinho S, Sari S, Mazzacuva F, Bilguvar K, Esendagli-Yilmaz G, Jain D, Akyol G, Dalgic B, Gunel M, Clayton PT, Lifton RP (2016) ACOX2 deficiency: a disorder of bile acid synthesis with transaminase elevation, liver fibrosis, ataxia, and cognitive impairment. Proc Natl Acad Sci USA 113: 11289-11293

38. Ferdinandusse S, Jimenez-Sanchez G, Koster J, Denis S, Van Roermund CW, Silva-Zolezzi I, Moser AB, Visser WF, Gulluoglu M, Durmaz O, Demirkol M, Waterham HR, Gokcay G, Wanders RJ, Valle D (2015) A novel bile acid biosynthesis defect due to a deficiency of peroxisomal ABCD3. Hum Mol Genet 24: 361-370

39. Gronemeyer T, Wiese S, Ofman R, Bunse C, Pawlas M, Hayen H, Eisenacher M, Stephan C, Meyer HE, Waterham HR, Erdmann R, Wanders RJA, Warscheid B (2013) The proteome of human liver peroxisomes: Identification of five new peroxisomal constituents by a label-free quantitative proteomics survey. PLoS One 8: 1-12

40. Ferdinandusse S, Falkenberg KD, Koster J, Mooyer PA, Jones R, van Roermund CWT, Pizzino A, Schrader M, Wanders RJA, Vanderver A, Waterham HR (2017) ACBD5 deficiency causes a defect in peroxisomal very long-chain fatty acid metabolism. J Med Genet 54: 330-337

41. Goldfischer S, Moore CL, Johnson AB, Spiro AJ, Valsamis MP, Wisniewski HK, Ritch RH, Norton WT, Rapin I, Gartner LM (1973) Peroxisomal and mitochondrial defects in the cerebro-hepato-renal syndrome. Science 182: 62-64

42. Brown FR, McAdams AJ, Cummins JW, Konkol R, Singh I, Moser AB, Moser HW (1982) Cerebro-hepato-renal (Zellweger) syndrome and neonatal adrenoleukodystrophy: similarities in phenotype and accumulation of very long chain fatty acids. Johns Hopkins Med J 151: 344-351

43. Heymans HSA, Schutgens RBH, Tan R, van den Bosch $H$, Borst $P$ (1983) Severe plasmalogen deficiency in tissues of infants without peroxisomes (Zellweger syndrome). Nature 306: 69-70
44. Stradomska TJ, Bachański M, Pawłowska J, Syczewska M, Stolarczyk A, Tylki-Szymańska A (2013) The impact of a ketogenic diet and liver dysfunction on serum Very Long- Chain Fatty Acids levels. Lipids 44: 405-409

45. Stradomska TJ, Tylki-Szymańska A (2001) Decreasing serum VLCFA levels in ageing X-ALD female carriers. J Inherit Metab Dis 24: 851-857

46. Stradomska TJ, Kubalska J, Janas R, Tylki-Szymańska A (2012) Reproductive function in men affected by of X-linked adrenoleukodystrophy/ adrenomyeloneuropathy. Eur J Endocrinol 166: 291-294

47. Hein S, Schonfeld P, Kahlert S, Reiser G (2008) Toxic effects of X-linked Adrenoleukodystrophy associated, very long chain fatty acids on glial cells and neurons from rat hippocampus in culture. Hum Mol Genet 17: $1750-1761$

48. Hubbard WC, Moser AB, Liu AC, Jones RO, Steinberg SJ, Lorey F, Panny SR, Vogt RF Jr, Macaya D, Turgeon CT, Tortorelli S, Raymond GV (2009) Newborn screening for X-linked adrenoleukodystrophy (X-ALD): validation of a combined liquid chromatography-tandem mass spectrometric (LC-MS/MS) method. Mol Genet Metab 97: 212-220

49. Ghosh A, Schlecht H, Heptinstall LE, Bassett JK, Cartwright E, Urquhart J, Broomfield A, Morris AA, Jameson E, Schwahn BC, Walter JH, Douzgou S, Murphy H, Hendriksz C, Sharma R, Wilcox G, Crushell E, Monavari AA, Martin R, Doolan A, Senniappan S, Ramsden SC, Jones SA, Banka S (2017) Diagnosing childhood-onset inborn errors of metabolism by next-generation sequencing. Arch Dis Child 102: 10191029

50. Ploski R, Pollak A, Müller S, Franaszczyk M, Michalak E, Kosinska J, Stawinski P, Spiewak M, Seggewiss H, Bilinska ZT (2014) Does p.Q247X in TRIM63 cause human hypertrophic cardiomyopathy? Circ Res 114: e2-e5.https://doi.org/10.1161/CIRCRESAHA.114. 302662

51. Klouwer FC, Berendse K, Ferdinandusse S, Wanders RJ, Engelen M, Poll-The BT (2015) Zellweger spectrum disorders: clinical overview and management approach. Orphanet J Rare Dis 10: 151

52. Berendse K, Engelen M, Linthorst GE, van Trotsenburg AS, Poll-The BT (2014) High prevalence of primary adrenal insufficiency in Zellweger spectrum disorders. Orphanet J Rare Dis 9: 133

53. Tylki - Szymańska A, Stradomska TJ (1995) Effect of glycerol trioleate oil milk formula administration on very long fatty acid levels and clinical course in a patient with Zellweger syndrome. Eur J Pediatr 154 867

54. Martinez M, Vazquez E, Garci-Sylva MT, Manzanares J, Bertran JM, Castello F (2000) Therapeutic effects of docosahexaenoic amid ethyl ester in patients with generalized peroxisomal disorders. Am J Clin Nutr 71: 376-385

55. Paker AM, Sunness JS, Brereton NH, Speedie LJ, Albanna L, Dharmaraj S, Moser AB, Jones RO, Raymond GV (2010) Docosahexaenoic acid therapy in peroxisomal diseases: results of a double-blind, randomized trial. Neurology 75: 826-830

56. Berendse K, Klouwer FC, Koot BG, Kemper EM, Ferdinandusse S, Koelfat KV, Lenicek M, Schaap FG, Waterham HR, Vaz FM, Engelen M, Jansen PL, Wanders RJA, Poll-The BT (2016) Cholic acid therapy in Zellweger spectrum disorders. J Inherit Metab Dis 39: 859-868

57. Sá MJ, Rocha JC, Almeida MF, Carmona C, Martins E, Miranda V, Coutinho M, Ferreira R, Pacheco S, Laranjeira F, Ribeiro I, Fortuna AM, Lacerda L (2016) Infantile Refsum Disease: Influence of Dietary Treatment on Plasma Phytanic Acid Levels. JIMD Rep 26: 53-60

58. Baldwin EJ, Gibberd FB, Harley C, Sidey MC, Feher MD, Wierzbicki AS (2010) The effectiveness of long-term dietary therapy in the treatment of adult Refsum disease, J Neurol Neurosurg Psychiatry 81: 954957

59. Moser HW, Raymond GV, Lu SE, Muenz LR, Moser AB, Xu J (2005) Follow-up of 89 asymptomatic patients with adrenoleukodystrophy treated with Lorenzo's oil. Arch Neurol 62: 1073-1080

60. Mahmood A, Raymond GV, Dubey P, Peters C, Moser HW (2007) Survival analysis of haematopoietic cell transplantation for childhood cerebral X-linked adrenoleukodystrophy: a comparison study. Lancet Neurol 6: 687-692

61. Miller WP, Rothman SM, Nascene D, Kivisto T, De-For TE, Ziegler RS, Eisengart J, Leiser K, Raymond G, Lund TC, Tolar J, Orchard PJ, (2011) 
Outcomes after allogeneic hematopoietic cell transplantation for childhood cerebral adrenoleukodystrophy: the largest single-institution cohort report. Blood 118: 1971-1978

62. Cartier N, Hacein-Bey-Abina S, Bartholomae CC, Veres G, Schmidt M, Kutschera I, Vidaud M, Abel U, Dal-Cortivo L, Caccavelli L, Mahlaoui N, Kiermer V, Mittelstaedt D, Bellesme C, Lahlou N, Lefrere F, Blanche S, Audit M, Payen E, Leboulch P, l'Homme B, Bougneres P, Von KC,
Fischer A, Cavazzana-Calvo M, Aubourg P (2009) Hematopoietic stem cell gene therapy with a lentiviral vector in X-linked adrenoleukodystrophy. Science 326: 818-823

63. Stradomska TJ, Drabko K, Moszczyńska E, Tylki-Szymańska A (2014) Monitoring of very long-chain fatty acids levels in X-linked adrenoleukodystrophy, treated with haematopoietic stem cell transplantation and Lorenzo's Oil. Folia Neuropathol 52: 159-163

\title{
Peroxisomal disorders
}

\section{Teresa J. Stradomska}

Department of Biochemistry and Experimenal Medicine, The Children's Memorial Health Institute, 20 Dzieci Polskich Ave., 04-730 Warsaw, Poland

e-mail: jstradomska@op.pl

Key words: peroxisomes, peroxisomal biogenesis disorders, single peroxisomale enzyme/transporter deficency, Zellweger syndrome, adrenoleukodystrophy, VLCFA

\begin{abstract}
Peroxisomes are multifunctional microorganelles that play a key role in numerous biochemical processes adapting dynamically to the current physiological requirements of the cell. The disturbance of the peroxisome structure due to mutations in different $P E X$ and non-PEX genes coding functional peroxisomal proteins is the pathogenic basis of the peroxisomal disorders. The $\beta$-oxidation process of very long-chain fatty acids (VLCFA) is a unique metabolic pathway located exclusively in the peroxisome. This determines that VLCFA is the main biomarker for the diagnosis of peroxisomal diseases. Peroxisomal disorders present a broad spectrum of clinical symptoms from the neonatal, severe Zellweger syndrome with dysmorphia, multi-organ dysfunction to the late symptomatic adult form of X-linked adrenoleukodystrophy. Relatively common the use of highly specialized analytical techniques causes it is a still growing group of rare metabolic diseases.
\end{abstract}

